\title{
IAMJ
}

INTERNATIONAL

AYURVEDIC

MEDICAL JOURNAL

Review Article

ISSN: 2320-5091

Impact Factor: 6.719

\section{CONCEPTUAL STUDY OF PUNARNAVASHTAKA KSHEERABASTI IN GARBHINI SHOTHA (EDEMA IN PREGNANCY.)}

\section{$\underline{\text { Vibha Sheshrao Adhave }}^{1}, \underline{\text { Vijay Nawale }}^{2}$}

${ }^{1}$ M.S. Scholar, P.G. Dept. of PrasutiTantra \& Stree Roga, SMBT Ayurvedic

College, Dhamangaon, Nashik, Maharashtra, India

${ }^{2}$ Associate Professor Guide. P.G. Dept. of PrasutuTantra \& Stree Roga, SMBT

Ayurvedic College Dhamangaon, Nashik, Maharashtra, India

Corresponding Author: vibhaadhave10@gmail.com

https://doi.org/10.46607/iamj2009052021

(Published Online: May 2021)

Open Access

(C) International Ayurvedic Medical Journal, India 2021

Article Received:27/04/2021 - Peer Reviewed:06/05/2021 - Accepted for Publication:08/05/2021

Check for updates

\section{ABSTRACT}

Pregnancy is most beautiful phase of a women's life its incredible journey that leads to great emotional fulfillment to women and Having a successful motherhood and continuation of pregnancy till term is very important. Garbhini Shotha (Edema in Gravidarum) is one of the most commonly found in Garbhini (Gravidarum) which mentioned in Garbhopadrava (Complications in pregnancy). There are 8 Upadravas (Complications) are mentioned in Harita Sanhita. On the basis of signs and symptoms Garbhini Shotha correlates with Pregnancy induced Hypertension (PIH) in Modern science. Number of causes have been Proposed but none of them has been proved It May leads to Preeclampsia which is life threatening convulsive disorder. Modern science has treatment on that, but it is not satisfactory it can lead side effects also so that I have tried to explain that Punarnavashtak Ksheerbasti this Ayurvedic Medicine can overcome this problem by its Shothaghna (removing swelling) and anti-hypertensive Properties. This drug act with their different Properties on basis of causative factors of disease in early stages.

Keywords: Garbhini Shotha, Punarnavashtak Ksheerbasti, Punarnavashtaka Kwatha, Edema in pregnancy 


\section{INTRODUCTION}

Numbers of cases of PIH are seen today due to lack of maternal nutrition and ante natal care. During the pregnancy maternal physiology altered due to fetus. According to modern science common causes of edema in pregnancy is Preeclampsia, Anemia, Proteinuria Clinically edema manifests as swelling. $75-80 \%$ of all pregnant women suffer from pitting edema is shown by study in second and third trimester of pregnancy. Increased blood flow during pregnancy and pressure of growing uterus on the pelvic veins and vena cava causes edema. It presents with mainly ankle edema which reduces on rest, unassociated with other features of preeclampsia, proteinuria, cardiac, renal and hematological pathologies. During pregnancy, the body requires an additional amount of fluid in order to meet the baby's requirements and to increase the blood circulation. Thus, the body continues to retain water with other features of Preeclampsia, proteinuria, cardiac, renal and hematological pathologies. The body requires an additional amount of Fluid for fetal development and increase blood circulation during pregnancy thus the body continues to retain water. Early diagnosis and treatment are necessary to reduce edema and prevent complication preeclampsia, renal failure, Hypertension, cardiac failure, Anaemia. According to Kashyap Samhita Main cause of Shotha is imbalance in Vata Dosha. According to Acharya Charaka pregnancy is very delicate stage and we have to treat it as possible as in early stage because it takes very short period to attain Daruna Avastha (Chronic Stage) and it becomes harmful for mother and fetus. One of important sign of preeclampsia is edema in pregnancy which is associated with hypertension and albuminurea and which may get complicated in the form of eclampsia.

\section{Literary Review of Garbhini Shotha:}

\section{Charak Samhita and Ashtang Hridaya:}

Direct reference of Garbhini Shotha does not mentioned in Charaka Samhita and Ashtanga Hridaya but Aacharya Charaka mentioned main cause of Shotha (Edema) is Garbha sampidan (Conception Compression) and Aacharya Vagbhata also mentioned cause of Shotha (edema) is Garbha (Foetus)

\section{Harita Samhita and Kashyapa Samhita:}

Garbhini Shotha has mentioned as Garbhoupdrava in both Samhita. But Kashyapa has mentioned treatment in Garbhini Chikitsa Adhyaya and Nidanpanchak of Shotha

\section{Yogratnakar:}

In Yog Ratnakar Chikitsa for GarbhiniShotha is mentioned in Garbha Roga Chikitsa.

\section{Rasratna Samuchchaya:}

In Rasratnasamuchchaya Garbhini Shotha Chikitsa is mentioned in Adhyaya 22 which contain Garbhini Shothahar Lepa and Kwatha.

\section{Pathophysiology of Garbhini Shotha (Edema in gravidarum):}

Due to enlarged gravid uterus, increased renin secretion dueto glomerular filtration rate is decreased and renal perfusion is impaired, which activates production of angiotensin - II. It is responsible for increase in aldosterone, which causes more retention of sodium by renal tubules. Water is also retained in tissue spaces with sodium to maintain the tonicity of body fluid and the part get distended and edema occurs

Nidan Panchak (pathophysiology):

Hetu (Causes):

Hetu performs multidimensional actions in the initiation of the disease process by aggravating Dosha.

All Neej Hetu of Shotha are classified as 1) Aharaj 2) Viharaj 3) Upadrava.

\section{Aharaj (Diet Induced) -}

\section{Rasapradhanya}

Excessive Lavan (Salty) and Amla (Sour) rasa causes Kapha, Pitta and Rakta Dushti.

\section{Gunapradhanya}

Excessive Guru (heavy and difficult to digest), excessive Ruksha (dry), Ushna Anna (Hot Food), Excessive Tikshna (Spicy), Vidahi, Abhishyandi.

Rupa of Shotha (Sign \& Symptoms) is mentioned in Charaksamhita as follows:

1. Gaurav (Heaviness)

2. Anavasthitatwa (Not confined to certain part).

3. Utsedh (Elevation due to accumulation of fluid)

4. Siratanutwa (Thinning of Vessels), Lomharsha, Vaivarnyatwa. 
Upashaya (Relief): Upashaya which is gives pleasure to those persons by using medicines, diet, and regimens their actions may be work directly against to cause or to the disease itself.

\section{Samprapti (Pathophysiology):}

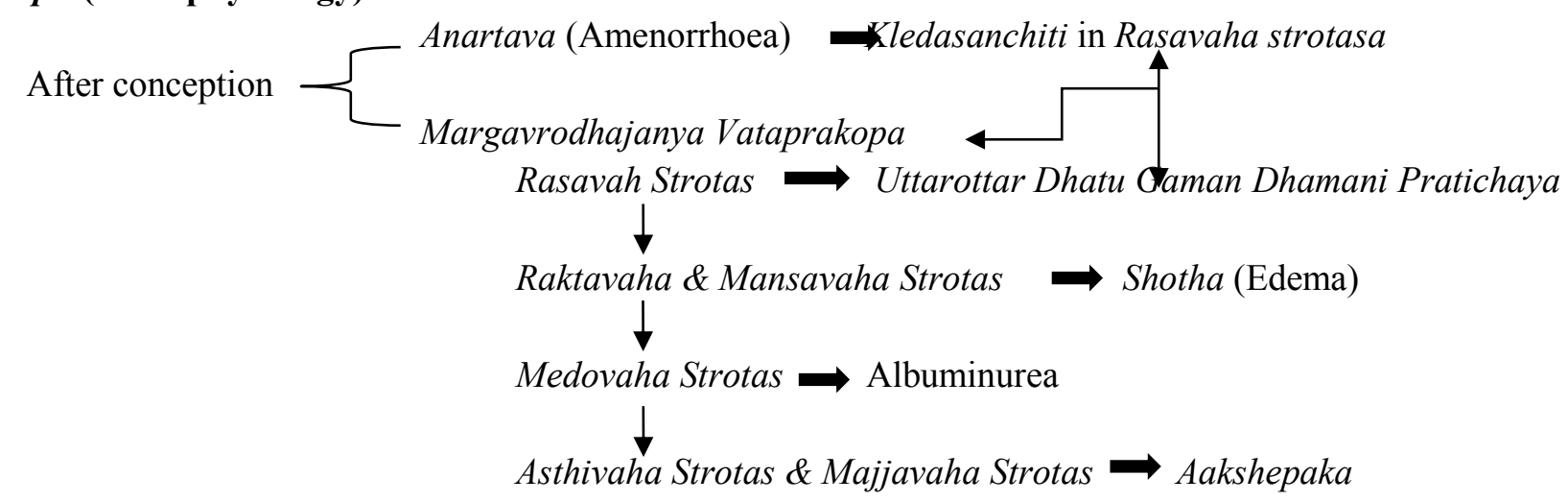

Table 1: Discussion of Drug

\begin{tabular}{|l|l|l|l|l|l|}
\hline SR. No & Drug & Latin name & Family & Part & Quantity \\
\hline 1 & $\begin{array}{l}\text { Punarnava (Spreading } \\
\text { hogweed) }\end{array}$ & Boerhavia Diffusa & Nictaginaceae & Root & 1 Part \\
\hline 2 & $\begin{array}{l}\text { Nimba } \text { (Indian Margosa } \\
\text { Tree) }\end{array}$ & Azadirachta indica & Meliaceae & Bark & 1 Parts \\
\hline 3 & Patola (Pointed gourd) & Trichosanthus Diocia & Cucurbitaceae & Leaves & 1 Parts \\
\hline 4 & Shunthi (Dry Ginger) & Zinziber Officinalis & Zinziberaceae & Rhizomes & 1 Parts \\
\hline 5 & Tikta (Picrorrhiza) & Picrorrhiza Kurro & Scrophulariaceae & Root & 1 Parts \\
\hline 6 & Abhaya (Myrobalan) & Terminalia chebula & combretaceae & Fruit & 1 Parts \\
\hline 7 & Darvi (Indian beriberi) & Berberis Aristata & berberidaceae & Root & 1 Parts \\
\hline 8 & Amruta & Tinospora cordifolia & menispermiaceae & Rhizomes & 1 Parts \\
\hline
\end{tabular}

Table 2: Properties and action of Punarnavashtaka Kwatha drug

\begin{tabular}{|l|l|l|}
\hline 1 & Punarnava & $\begin{array}{l}\text { Relieves edema, anti-inflammatory, diuretic, hepatoprotective, act on urinary disorders, reduce } \\
\text { water retention and edema. }\end{array}$ \\
\hline 2 & Nimba & $\begin{array}{l}\text { Alleviates Pitta, stimulates liver, relieves edema, diuretic, stomachic, anti-inflammatory, hepato- } \\
\text { protective, reduce urinary disease }\end{array}$ \\
\hline 3 & Patola & $\begin{array}{l}\text { Mild purgative, rejuvenator, stomachic, stimulates liver, anti-inflammatory, uterine tonic, cures } \\
\text { dysuria and retention of urine, reduces congestion, relieves edema and abdominal disorders. }\end{array}$ \\
\hline 4 & Shunthi & $\begin{array}{l}\text { Aampachana (digests the undigested un-metabolized food), rejuvenator, relieves edema, sto- } \\
\text { machic, carminative, anti-inflammatory }\end{array}$ \\
\hline 5 & Tikta & $\begin{array}{l}\text { Alleviates Pitta, stimulates liver, relieves edema, diuretic, stomachic, anti-inflammatory, hepato- } \\
\text { protective, reduce urinary disease, }\end{array}$ \\
\hline 6 & Abhaya & $\begin{array}{l}\text { Uterine tonic, cures dysuria and retention of urine, reduces congestion, relieves edema and ab- } \\
\text { dominal disorders. }\end{array}$ \\
\hline 7 & Darvi & $\begin{array}{l}\text { Antiinflammatory, appetizer, hepato-protective, reduce water retention, immuno-stimulatory, re- } \\
\text { lieves urinary tract infection. }\end{array}$ \\
\hline 8 & Amruta & $\begin{array}{l}\text { Mild diuretic, immuno-modulator, antioxidant, curative of edema, urinary disorders, burning } \\
\text { sensation, anemia, dysuria and abdominal related disorders. }\end{array}$ \\
\hline
\end{tabular}

\section{DISCUSSION}

Lower socioeconomic Status and middle-class female are more prone to Garbhini Shotha due to symptoms of Malnutrition.
Shothagna effect of Punarnavashtak Kwatha in Garbhini Shotha This drug is used in the form of Ksheerapaka Basti form this form has Katu, Tikshna, Ruksha properties that are normalise with milk Sheeta 
(cold), Madhura (sweet), Snigdha (unctuous) properties. Also, in the Basti (Enema) form, large quantity of drug can be delivered without any undue issues on palatability or any other side effects.

Shotha is mainly kapha-Vataja in nature Punarnavadi Kwatha has Katu Tikta Kashaya, Dipan, Pachana in nature they are act as Kaphavatshamak, Kledghna, Shophghna, Mutral, Rasshodhna of Strotasa. It decreases Kledasanchiti by its Mutravruddhi and Kaphavatshamana and Shothaghna.

Main contents of this drug are Punarnavait has Katu, Tikta, Kashaya Rasa, Ushna Virya and Katu Vipaka, Vata-Kaphaghna, hence reduces Kleda in body. Punarnava is one of the most Shothaghna drugs without any side-effects. It contains unusual large quantity of potassium nitrate partly accounts for its diuretic property. It is haematinic and growth promoter. Shothahara properties present in the formulations plays major role in reducing the edema. It flushes out the toxins and excess fluid retention due to the diuretic action of the drugs, relieving the complaints of urine infection and scanty micturation. Immunomodulatory and Rasayana (rejuvenator) properties are beneficial in overcoming Garbhini Vyadhi (disorders in pregnancy). Vatanulomana (carminative), Deepana and Pachana (stomachic) properties act on Agni (digestive fire), normalizing the digestion and metabolism. Pain is subsided by the Shoolahara (analgesic) action of the formulation. Many of the contents have Yakrut-Uttejaka Guna (stimulates liver) along with action on Pandu (anaemia). Therefore, the formulation may have positive effect on Rakta Dhatu (blood and circulatory system) thereby preventing anaemia in pregnant lady. Milk further nourishes the tissues of mother and the foetus.

\section{CONCLIUSION}

Punarnava has anti-inflammatory action. It has Also Cardiotonic Property, it reduces Blood pressure, its diuretic Property due to large amount of potassium and presence of alkaloid Punarnavine So excrete Excess water from the body and it decreases edema. It relieves the edema, reduces the water retention and also cures burning \& scanty micturation along with urinary tract infections efficiently. Endowed with immunomodulatory, antioxidant, adaptogenic, hepatoprotective properties, it rules out any side effect of the drug on the growing foetus.

\section{REFERENCES}

1. DC Dutta. Textbook of Obstetrics, 6th Edition. Kolkata; New Central Book Agency Pvt Limited Publication; 2004.

2. Narendra Malhotra, Randheer Puri, Jaideep Malhotra, Manual of practical problem in obstretics, Hypertensive disorder in pregnancy, 1st edition, Jaypee publications, page

3. Harit Samhita, Jivanandvidyasagar bhattachyarya, sanskrut prakashan, part I

4. Garbhopdrav chikista, page no. 284.Charak samhita, vidyotini tika, sutra sthana 18/6, fourth edition,1992, Choukhamba publication, Varanasi.

5. Prof. Priyavat Sharma, Dhanvantari Nighantu, Dravya Guna Vidnyan,Choukhamba Bharti Academy.

6. Jadavji T. Dravya guna Vignana, 2nd ed. Mumbai: Satyabhamabaipanduranga nirnayasagaramudrana yantralaya; Uttarardha paribhasha khanda, 1947; 33-34

7. Vaidya VM Gogte. Ayurvedic Pharmacology and Therapeutic Uses of Medicinal Plants, Dravyagunavijnana. New Delhi; Chaukhambha publications; 2012. p. 314, 326, 360, 395, 410, 416, 428, 517.

8. Kavirajshri Ambikadattashastri Ayurvedacharya. Bhaishajya Ratnavali. Varanasi; Chaukhambha Sanskrit Samsthan; 2002. p. 532.

9. Charaka Sutra 27/127, Agnivesh, Charaka Samhita, ed. By Shree Satyanarayana Shashtri, Chaukhambha Bharati Academy Varanasi, 2008.

10. Charaka Siddhisthana.1/37, 971. Agnivesh, Charaka Samhita, ed. By Shree Satyanarayana Shashtri, Chaukhambha Bharati Academy Varanasi, 2008.

11. Charaka Siddhisthana. 1/37, 971. Agnivesh, Charaka Samhita, ed. By Shree Satyanarayana Shashtri, Chaukhambha Bharati Academy Varanasi, 2008.

\section{Source of Support: Nil \\ Conflict of Interest: None Declared}

How to cite this URL: Vibha Sheshrao Adhave \& Vijay Nawale: Conceptual Study Of Punarnavashtaka Ksheerabasti In Garbhini Shotha (Edema In Pregnancy.). International Ayurvedic Medical Journal \{online\} 2021 \{cited May, 2021\} Available from: http://www.iamj.in/posts/images/upload/1067 1070.pdf 